\title{
Cascade Control Using Soft Sensor for Aldehide Column Energy Saving
}

\author{
Totok R. Biyanto ${ }^{1}$
}

\begin{abstract}
The focus of this paper is to develop the control strategy on aldehyde distillation column. The objectives are to maintain the consistency of product's composition, energy saving and optimum cost.

The method is replacing the control structure from inferential control to cascade control using $L V$ structure, with soft sensor to improve performance, reduce cost and increase reliability.

The disturbance was given by a change in the mole flow rate of feed. Cascade control with $\mathrm{LV}$ structure was proposed to minimize Internal Absolute Error (IAE) and increase energy efficiency. The result of this research showed that cascade control with LV structure had a lower Integral Absolute Error (IAE) than inferential control structure, improved product composition consistency, and increased energy efficiency.
\end{abstract}

Keywords - Energy saving, Aldehyde distillation column, Control structure

\section{PEndahuluan}

$\mathrm{K}$ onsumsi energi kolom aldehid yang memisahkan isobutyraldehyde (i-butanal) dan normalbutyraldehyde (n-butanal) dari crude aldehyde adalah sangat besar, yaitu mencapai $40 \%-50 \%$ dari total biaya operasinya [1], [2]. Hal ini akan menyebabkan biaya produksi yang besar, apalagi ditengah harga LPG yang melambung yang merupakan bahan bakar boiler.

Kelangkaan bahan baku berupa gas alam membuat kolom distilasi aldehid tidak bisa berproduksi sesuai kapasitas yang optimal [3], sehingga mengurangi laju aliran umpan pada kolom distilasi aldehid, yang pada akhirnya menurunkan laju produksi. Namun penurunan laju produksi tidak sebanding dengan besarnya dengan penurunan laju panas pada reboiler, sehingga efisiensi pemakaian energi terhadap hasil proses menurun.

Penurunan laju aliran umpan pada kolom distilasi pada umumnya akan menggangu kualitas atau komposisi produk yang merupakan prioritas utama yang harus dicapai dan dipertahankan melalui kontrol proses [4], [5].

Untuk meminimalkan konsumsi energi pada kolom distilasi dapat dilakukan dengan cara penerapan integrasi panas pada kolom distilasi [4], [2], [1]. Namun untuk penerapan integrasi panas harus merubah kondisi operasional kolom distilasi. Hal ini sulit dilakukan karena selain biaya yang sangat mahal dan memakan waktu yang lebih lama, kolom distilasi aldehid ini sudah terpasang dan harus terus beroperasi. Untuk mengatasi hal itu maka alternatif lain adalah merubah strategi kontrol yang sudah terpasang dengan strategi kontrol yang mampu mengatasi terjadinya gangguan dan dapat menghemat energi.

Naskah diterima 5 Mei 2006; selesai revisi pada 21 April 2008

1 Totok R.B. adalah dosen Jurusan Teknik Fisika, FTI, Institut Teknologi Sepuluh Nopember, Surabaya, INDONESIA (e-mail: trb@ep.its.ac.id)
Permasalahan pertama adalah bagaimana strategi kontrol yang dapat menjaga komposisi produk tetap stabil dan juga sekaligus bisa meminimalkan pemakaiaan energi [5]. Kedua adalah instrumentasi apa yang bisa dimanfaatkan untuk kepentingan startegi kontrol tanpa merubah instrumentasi yang ada, reliabel, mempunyai performansi yang baik dan menghemat biaya [6].

Penelitian ini bertujuan untuk mencari alternatif strategi kontrol pada kolom distilasi untuk proses pemisahan isobutyraldehyde dan normalbutyraldehyde yang dapat menjaga kestabilan komposisi produk dan tahan terhadap gangguan, meminimalkan penggunaan energi, khususnya energi panas pada reboiler serta menerapkan soft sensor sebagai pengganti instrumen analiser.

\section{TEORI PENUNJANG}

\section{A. Proses Kolom Aldehid}

Dalam proses produksi octanol terdapat kolom distilasi aldehid pada salah satu bagian prosesnya. Kolom aldehid mempunyai produk atas berupa isobutyraldehyde atau disingkat i-butanal dan produk bawah berupa normalbutyraldehyde atau disingkat n-butanal. Feed dari kolom aldehid adalah crude aldehyde yang merupakan hasil dari proses syn gas plant yang telah dipisahkan dari katalisnya. Produk dari kolom aldehid ini yang akan diproses lebih lanjut menghasilkan octanol sebagai produk utama, normal butyl alcohol dan isobutil alkohol sebagai produk sampingan.

Secara umum pemisahan komponen menggunakan kolom distilasi seperti pada Gambar 1, dimana laju aliran umpan $\mathrm{F}$, dengan komposisi $\mathrm{X}_{\mathrm{f}}$ masuk pada tray tertentu pada kolom. Terpisah karena perbedaan volatilitas menjadi produk atas atau distilat dengan laju aliran D dan komposisi $\mathrm{X}_{\mathrm{d}}$ dan produk bawah dengan laju aliran $\mathrm{B}$ dan komposisi $\mathrm{X}_{\mathrm{b}}$.

\section{B. Sistem Kontrol Direct}

Sistem kontrol direct seperti Gambar 2 adalah suatu metode kontrol yang bekerja berdasarkan informasi yang diperoleh secara langsung dari variabel yang ingin diukur/dikendalikan yaitu $X_{d}$ dan $X_{b}$. Dari sensor $X_{d}$ dihubungkan ke pengendali XIC-100 dan mengerakkan valve pada reflux, sedangkan sensor $\mathrm{X}_{\mathrm{b}}$ dihubungkan ke pengendali XIC-101 dan mengerakkan valve pada Qr. Pada kolom distilasi, sistem kontrol direct diaplikasikan pada pengukuran komposisi yang menggunakan analiser. Kelebihan analiser adalah hasil pengukuran yang dihasilkannya lebih akurat. Namun terdapat pula beberapa kelemahan, yaitu adanya keterlambatan (lag) dalam pengenalan komposisinya yang akan mengganggu performansi dari sistem, reliabiliti dari analiser yang rendah dan mahal [6], [7], [8]. 


\section{Sistem Kontrol Inferensial}

Pengukuran terhadap suatu variabel dapat dilakukan secara tidak langsung berdasarkan informasi dari variabel yang lain dan dikenal sebagai metode inferensial. Seperti pada Gambar 3, pengendalian komposisi $\mathrm{X}_{\mathrm{d}}$ dilakukan dengan mengendalikan laju reflux sedangkan pengendalian komposisi $\mathrm{X}_{\mathrm{b}}$ dilakukan dengan mengendalikan temperatur pada tray ke 32 . Kelemahan yang terjadi pada analiser (metode sistem kontrol direct) dapat diatasi dengan menggunakan metode ini. Salah satu strategi yang sering digunakan untuk sistem kontrol inferensial adalah dengan mengggunakan termodinamik sensor misalnya temperatur, laju aliran dan tekanan sebagai pengganti dari analiser pada sistem kontrol direct. Namun sistem kontrol ini tidak dapat menjaga konsistensi komposisi atau kualitas produk bila ada perubahan pada pengganggu proses dengan multi komponen.

\section{Sistem Kontrol Cascade}

Sistem kontrol cascade seperti Gambar 4, dengan sensor $\mathrm{X}_{\mathrm{d}}$ dihubungkan ke pengendali XIC-100 dan memberikan setpoint pada FIC-100 sebagai pengendali laju aliran reflux, sedangkan sensor $\mathrm{X}_{\mathrm{b}}$ dihubungkan ke pengendali XIC-101 dan setpoint pada TIC-100 sebagai pengendali temperatur pada tray ke 32 .
Konsep dari sistem kontrol cascade adalah menjadikan variabel termanipulasi dari master loop kontrol sebagai setpoint untuk slave loop kontrol.

Pada kolom distilasi aldehid terdapat dua buah sistem kontrol cascade yang diterapkan, yaitu loop kontrol komposisi distilat (Xd) sebagai master loop dengan kontrol flow pada reflux sebagai slave loop, dan kontrol komposisi bottom produk (Xb) sebagai master loop dengan kontrol temperatur tray sebagai slave loop.

Sistem kontrol cascade pada penelitian ini digunakan untuk mengurangi error yang disebabkan oleh gangguan dari sistem yang biasa terjadi pada kontrol inferensial dan mengurangi lag sistem pengukuran pada kontrol direct.

\section{E. Jaringan Syaraf Tiruan (JST) dengan Algoritma Belajar Levenbeg Marquard}

Struktur jaringan saraf tiruan yang umum adalah $m u l$ tilayer perceptron (MLP). Gambar 5 menggambarkan struktur MLP, yang terdiri dari input, hidden dan output layer. Secara matematis MLP dapat ditulis :

$$
y_{i}=F_{i}\left[\sum_{j=1}^{n_{h}} w_{i, j} \cdot f_{j}\left(\sum_{l=1}^{n_{\varphi}} w_{j, 1} \varphi_{1}+w_{j, 0}\right)+W_{i, 0}\right]
$$

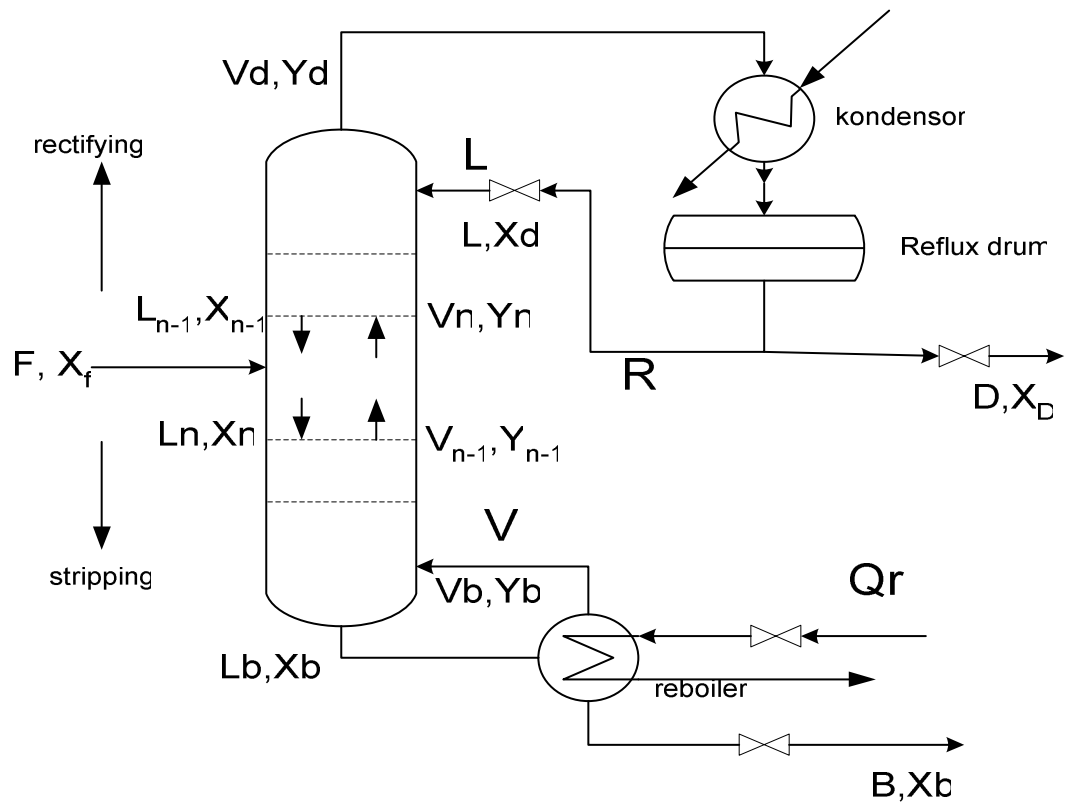

Gambar 1. Kolom distilasi biner 


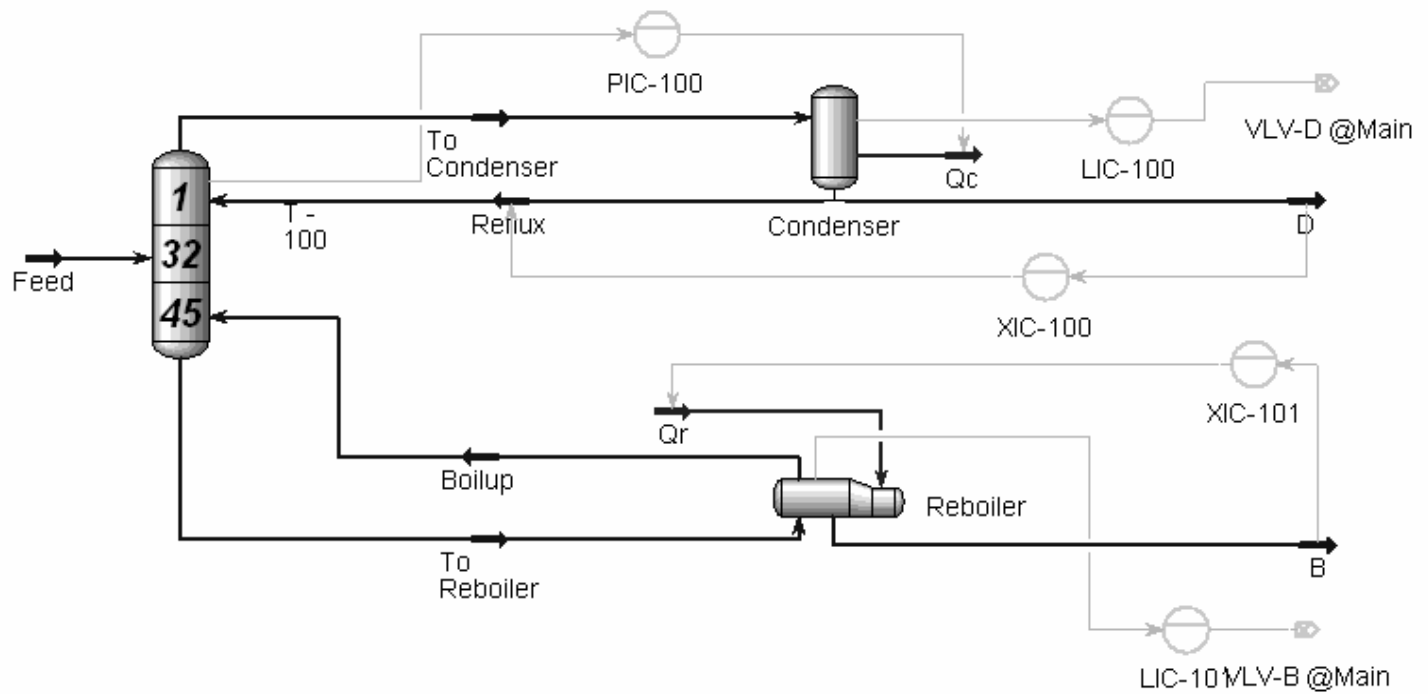

Gambar 2. Sistem kontrol direct pada kolom aldehid

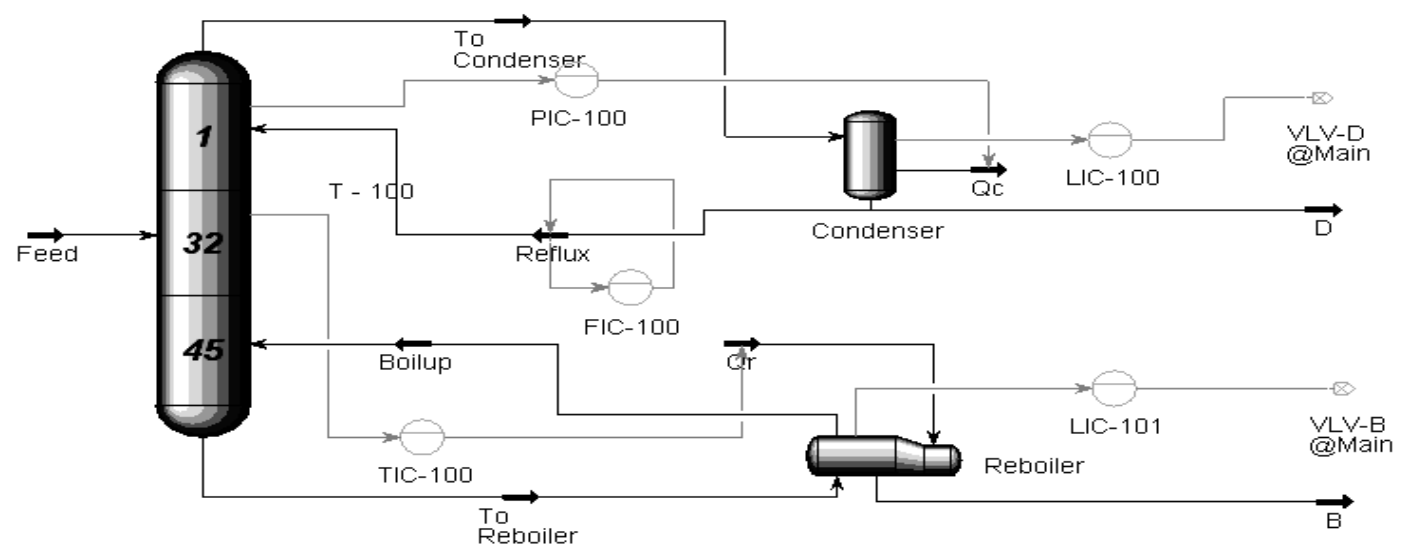

Gambar 3. Sistem kontrol inferensial pada kolom aldehid

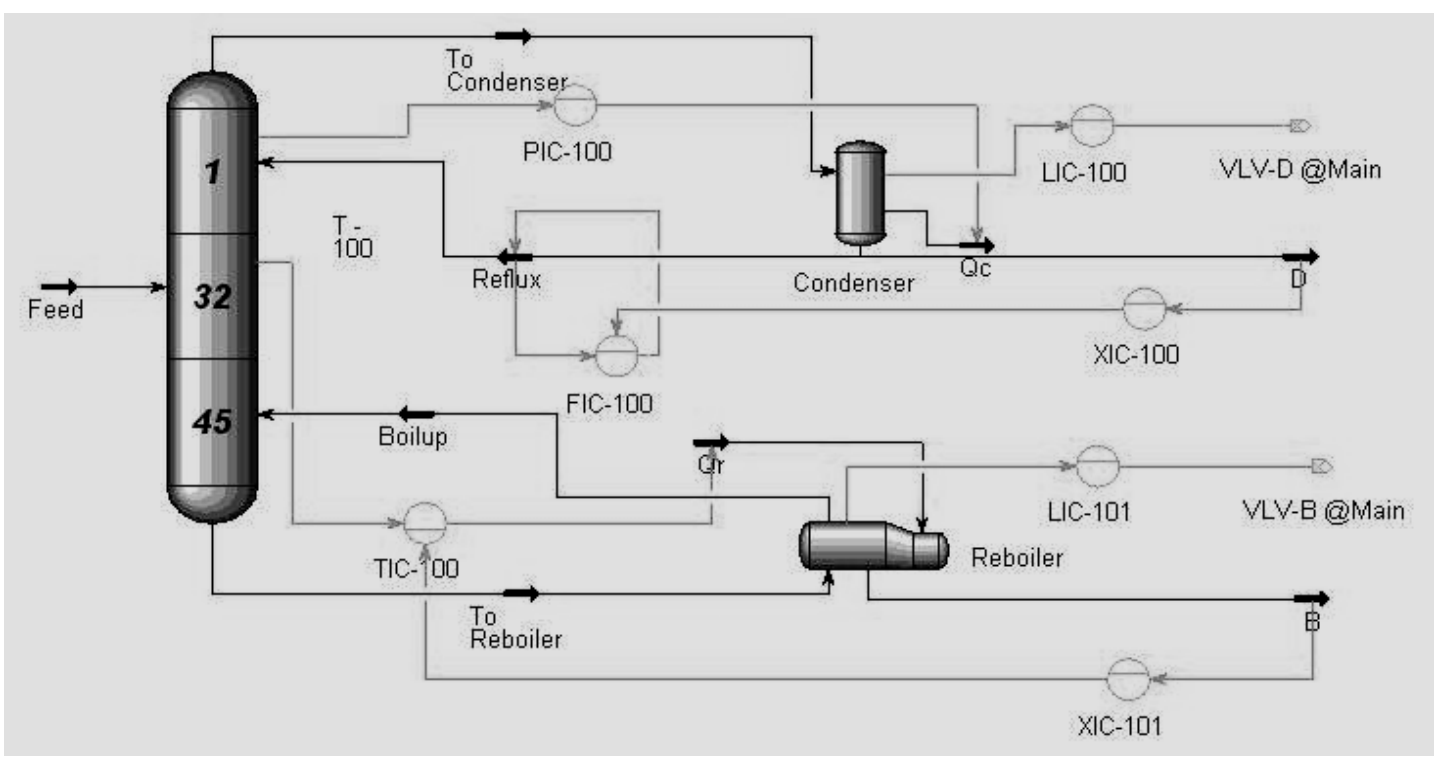

Gambar 4. Sistem kontrol cascade pada kolom aldehid 
Algoritma pembelajaran yang digunakan dalam penelitian ini adalah algoritma Levenberg Marquardt yang dapat di ringkas sebagai berikut [9]:

1. Pilih vektor bobot awal $\mathrm{w}^{(0)}$ dan harga awal $\lambda^{(0)}$.

dimana $w$ adalah bobot dan $\lambda$ diberikan harga awal

2. Tentukan arah pencarian

$\left[\mathrm{R}\left(\mathrm{W}^{(\mathrm{i})}+\lambda^{(\mathrm{i})} \mathrm{I}\right] \mathrm{f}^{(\mathrm{i})}=-\mathrm{G}\left(\mathrm{w}^{(\mathrm{i})}\right)\right.$

maka diperoleh $\mathrm{f}$ dan dimasukkan ke :

$\mathrm{w}=\arg \min _{\mathrm{w}} \mathrm{V}_{\mathrm{N}}\left(\mathrm{w}, \mathrm{Z}^{\mathrm{N}}\right)$

$\mathrm{w}^{(\mathrm{i}+1)}=\mathrm{w}^{(\mathrm{i})}+\mu^{(\mathrm{i})} \mathrm{f}^{(\mathrm{i})}$

Jika VN ( w(i) + f(i), ZN) < VN ( w(i), ZN) sehingga memenuhi $\mathrm{w}(\mathrm{i}+1)=\mathrm{w}(\mathrm{i})+\mathrm{f}(\mathrm{i})$ sebagai iterasi baru maka $\lambda(i+1)=\lambda(i)$. Jika tidak maka mencari $\lambda$ baru dari harga $\mathrm{r}$

$r^{(i)}=\frac{V_{N}\left(w^{(i)}, Z^{N}\right)-V_{N}\left(w^{(i)}+f^{(i)}, Z^{N}\right)}{V_{N}\left(w^{(i)}, Z^{N}\right)-L^{(i)}\left(w^{(i)}+f^{(i)}\right)}$

Jika $\mathrm{r}^{(\mathrm{i})}>0.75$ maka $\lambda^{(\mathrm{i})}=\lambda^{(\mathrm{i})} / 2$.

Jika $\mathrm{r}^{(\mathrm{i})}<0.25$ maka $\lambda^{(\mathrm{i})}=2 \lambda^{(\mathrm{i})}$.

Dimana :

$$
\begin{aligned}
& \mathrm{V}_{\mathrm{N}}\left(\mathrm{w}, \mathrm{Z}^{\mathrm{N}}\right)=\mathrm{L}^{(\mathrm{i})}(\mathrm{w}) \\
& =\frac{1}{2 \mathrm{~N}} \sum[\mathrm{y}(\mathrm{k})-\hat{\mathrm{y}}(\mathrm{k} \mid \mathrm{w})]^{\mathrm{T}}[\mathrm{y}(\mathrm{k})-\hat{\mathrm{y}}(\mathrm{k} \mid \mathrm{w}] \\
& L^{(i)}\left(w^{(i)}+f^{(i)}\right)=\left(\lambda^{(\mathrm{i})} f^{(i) \mathrm{T}} f^{(i)}\right)-\left(f^{(i) \mathrm{T}} \mathrm{G}\right)
\end{aligned}
$$

3. Jika kriteria tercapai, maka perhitungan berhenti. Jika kriteria belum tercapai maka mengulangi langkah no 2

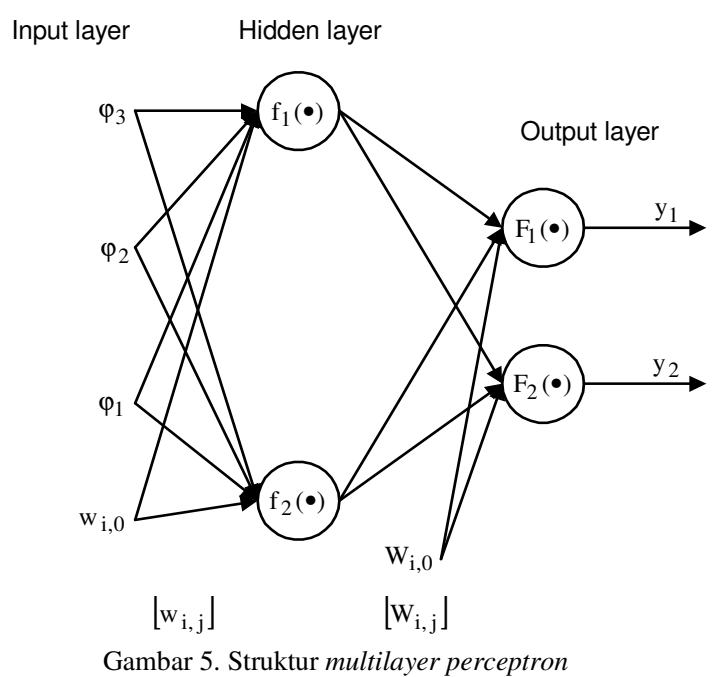

\section{F. Struktur Dan Training JST}

Pemodelan pada penelitian ini akan menggunakan JST - MLP (Neural Network - Multi Layer Percepton) dengan struktur ARX (AutoRegressive, eXternal input) dimana variabel input JST mengandung input (U) dan output (Y) masa sekarang dan lampau [6], [9]. Persamaan output model $\hat{Y}$ dapat ditulis sebagai berikut :

$\hat{Y}=f\left(Y_{1}, Y_{2}, U_{1}, U_{2}\right)$

dimana :

$$
\begin{aligned}
& \hat{Y}=\left[\hat{y}_{1}(k+1) \hat{y}_{2}(k+1)\right]^{T} \\
& Y_{1}=\left[y_{1}(k), y_{1}(k-1), \cdots, y_{1}\left(k-n y_{1}\right)\right] \\
& Y_{2}=\left[y_{2}(k), y_{2}(k-1), \cdots, y_{2}\left(k-n y_{2}\right)\right] \\
& U_{1}=\left[u_{1}(k), u_{1}(k-1), \cdots, u_{1}\left(k-n u_{1}\right)\right] \\
& U_{2}=\left[u_{2}(k), u_{2}(k-1), \cdots, u_{2}\left(k-n u_{2}\right)\right]
\end{aligned}
$$

dimana ny dan nu adalah history length untuk output dan input proses.

Gambar 6 adalah JST MLP dengan struktur input ARX dengan jumlah layer dan fungsi aktifasi [10]. Pada saat awal pelatihan dengan bobot model diambil secara acak, maka Y dan Yhat akan menunjukkan harga yang berbeda pada seluruh data set pelatihan atau masih ada error (e). Error ini adalah fungsi tujuan yang akan diminimisasi pada setiap iterasi atau epoch selama pelatihan menggunakan algoritma Levenberg Marquard dengan mengubah bobot W1 dan W2 pada JST.

Validasi model yang telah dibuat terhadap plant dilakukan dengan memberikan input yang belum pernah dilatihkan kepada JST dan mencatat Root Mean Squared Error (RMSE) yang terjadi sepanjang N sampel validasi [11], seperti Gambar 7 RMSE dapat ditulis sebagai berikut :

RMSE

$$
=\sqrt{\frac{\sum_{i=1}^{N}\left(y_{i}-\hat{y}_{i}\right)^{2}}{N}}
$$

\section{METODE PENELITIAN}

Dalam perancangan ini, langkah-langkah yang dilakukan untuk mencapai tujuan penelitian adalah sebagai berikut :

1. Pemodelan aldehide column menggunakan Hysys 3.2

2. Pengambilan data untuk training JST soft sensor.

3. Pembuatan strategi kontrol inferensial seperti yang terpasang pada plant saat ini dan cascade control sebagai strategi kontrol yang diajukan .

4. Pengujian sistem kontrol

5. Analisa data hasil pengujian

\section{AnAlisa Data dan PEMBahasan}

Uji penurunan laju aliran umpan turun adalah berdasarkan kejadian sebenarnya pada plant dimana suplai gas alam sebagai bahan baku utama plant mengalami kelangkaan. Laju aliran umpan pada kondisi operasi normal adalah $271.27 \mathrm{kmol} / \mathrm{jam}$, komposisi umpan 0.1 i-butanal dan 0.9 n-butanal, light key pada produk bawah (i-butanal) 0.01 dan Heavy key pada distilat (nbutanal) 0.01

Laju aliran umpan pada kondisi operasi normal adalah $271.27 \mathrm{kmol} / \mathrm{jam}$. Sesuai ganguan di plant maka disimulasikan penurunan laju aliran umpan menjadi 250 $\mathrm{kmol} / \mathrm{jam}$ pada jam pertama sampai jam ke enam dan diturunkan lagi sampai menjadi $225 \mathrm{kmol} / \mathrm{jam}$ pada jam ke enam sampai jam ke sembilan (Gambar 8). 


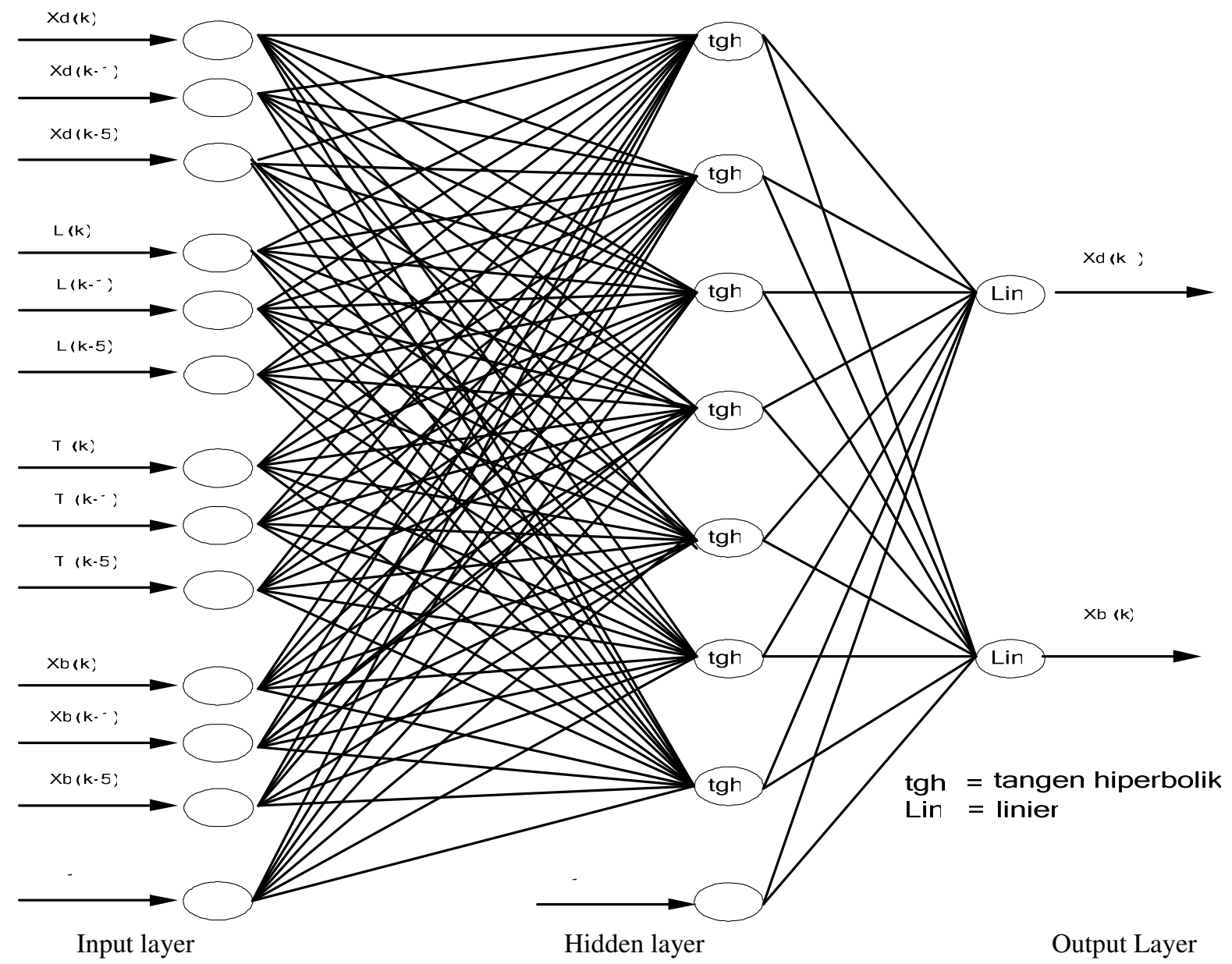

Gambar 6. Struktur JST soft sensor rancangan
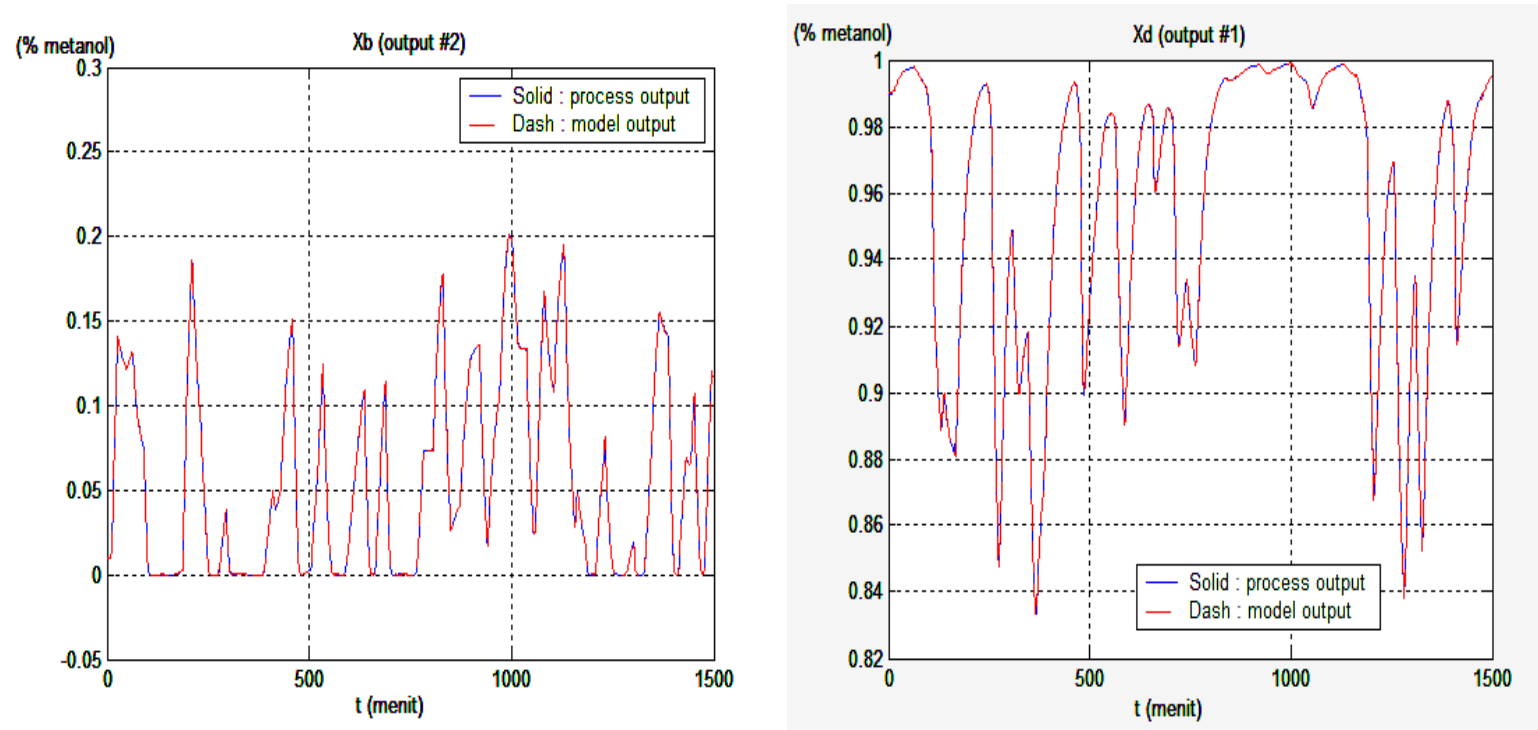

Gambar 7. Xd dan Xb dari proses dan JST soft sensor

Gambar 9 menunjukkan bagaimana respon komposisi produk atas dengan kontrol secara cascade dan inferensial ketika terjadi penurunan laju aliran umpan. Pada kontrol secara cascade komposisi produk atas selalu kembali mendekati nilai setpoint walaupun pada setiap penurunan laju aliran unpan dan terjadi overshoot yang kecil, yaitu maksimumnya sebesar 0.0002 dari nilai setpoint dan diperoleh nilai IAE sebesar 0.76972. Sedang untuk respon komposisi produk atas dengan kontrol secara inferensial, komposisi produk atas terus naik hingga mencapai nilai 0.995594 dan didapatkan nilai IAE sebesar 152.0986.

Kenaikan nilai komposisi produk atas pada kontrol secara inferensial disebabkan tidak adanya kontrol 
secara langsung terhadap komposisi. Ketika laju aliran umpan turun akan menyebabkan laju aliran distilat juga turun dan laju aliran refluk tetap karena dikendalikan, maka nilai refluk rasio yaitu perbandingan antara laju aliran refluk dan laju aliran distilat semakin besar. Dengan bertambahnya nilai refluk rasio ini maka, komposisi produk atas juga semakin besar atau semakin murni.

Komposisi produk bawah dengan kontrol secara inferensial nilainya menurun ketika terjadi penurunan laju aliran umpan (Gambar 10). Penurunan ini menyebabkan nilai IAE yang cukup besar, yaitu 32.22162. Nilai IAE komposisi produk bawah dengan kontrol secara inferensial sangat jauh bila dibandingkan dengan kontrol secara cascade yang hanya sebesar 0.01196 . Komposisi produk bawah dengan kontrol secara cascade walaupun terlihat

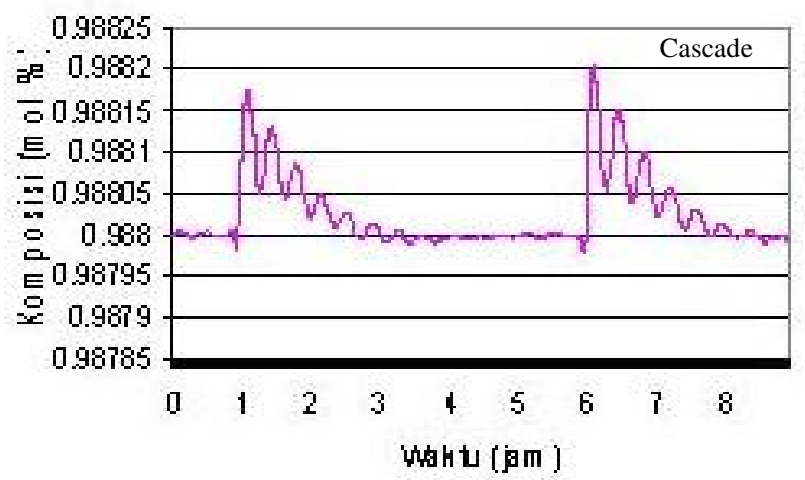

Gambar 9. Xd karena penurunan laju aliran umpan pada kontrol secara cascade dan inferensial

Penurunan nilai komposisi produk bawah dengan kontrol secara inferensial disebabkan adanya kenaikan komposisi produk atas. Sehingga komposisi produk bawah harus turun sesuai dengan kesetimbangan pada kolom distilasi. Pada kontrol cascade, komposisi produk bawah dikendalikan secara langsung dengan memanipulasi laju panas pada reboiler. Sehingga ketika ada penurunan laju aliran umpan, komposisi produk bawah akan berubah, namun kembali lagi sesuai setpoint.

Gambar 11 menunjukkan perubahan Qr sebagai variabel termanipulasi untuk mempertahankan komposisi $\mathrm{Xb}$ pada kontrol cascade dan mempertahankan temperatur tray ke 32 pada kontrol inferensial, saat terjadi gangguan penurunan laju aliran umpan dan interaksi dari perubahan komposisi Xd.

Saat terjadi penurunan laju aliran umpan, pada kontrol secara cascade aksi Qr akan sepadan dengan perubahan komposisi $\mathrm{Xb}$ sebagai tujuan utama yang harus dijaga, berosilasi, namun dalam range yang sangat kecil yaitu sekitar plus minus 0.0005 dari nilai setpoint yang ditentukan.

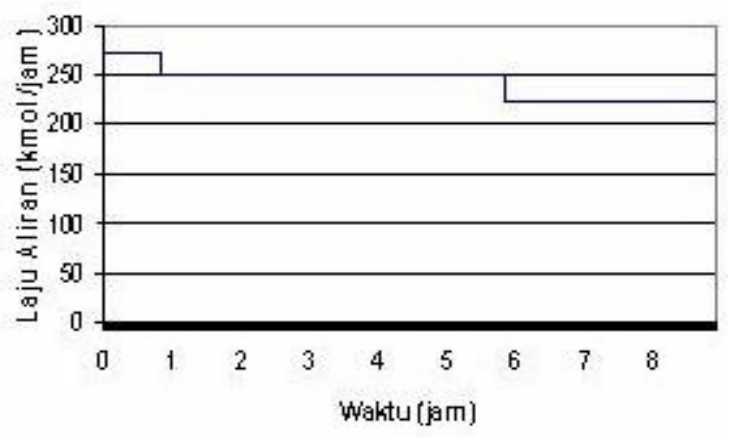

Gambar 8. Penurunan laju aliran umpan terhadap waktu

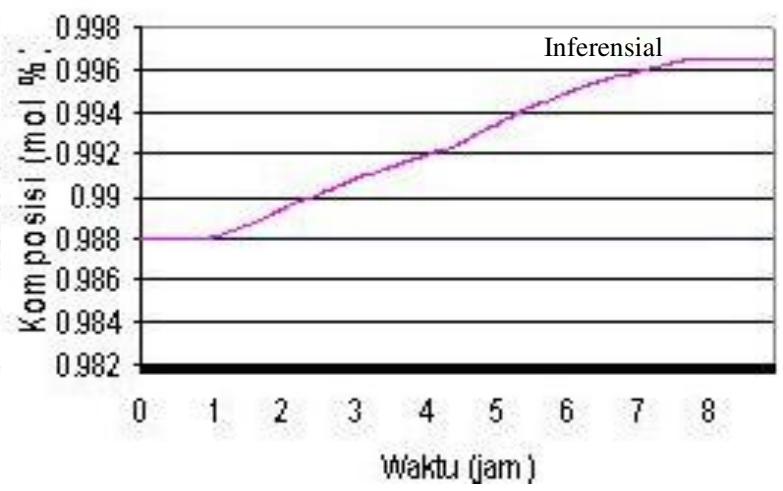

sedangkan interaksi dari perubahan komposisi $\mathrm{Xd}$ sangat kecil karena komposisi Xd sendiri dapat terkendali dengan baik. Namun pada pengendalian inferensial komposisi $\mathrm{Xd}$ tidak terkendali saat terjadi perubahan laju aliran umpan (Gambar 9) sehingga berinteraksi pada komposisi Xb. Ditambah lagi kesalahan prediksi komposisi $\mathrm{Xb}$ yang diwakili oleh temperatur pada tray ke 32 (Gambar 10), sehingga kontrol inferensial tidak dapat menjaga konsistensi komposisi $\mathrm{Xd}$ dan $\mathrm{Xb}$ saat perubahan laju aliran umpan dan interaksinya. Aksi Qr sebagai respon untuk mempertahankan komposisi $\mathrm{Xb}$ yang diprediksi dengan pendekatan temperatur pada tray ke 32 adalah perpaduan aksi dalam menanggapi perubahan laju aliran feed dan interaksi dari perubahan Xd.
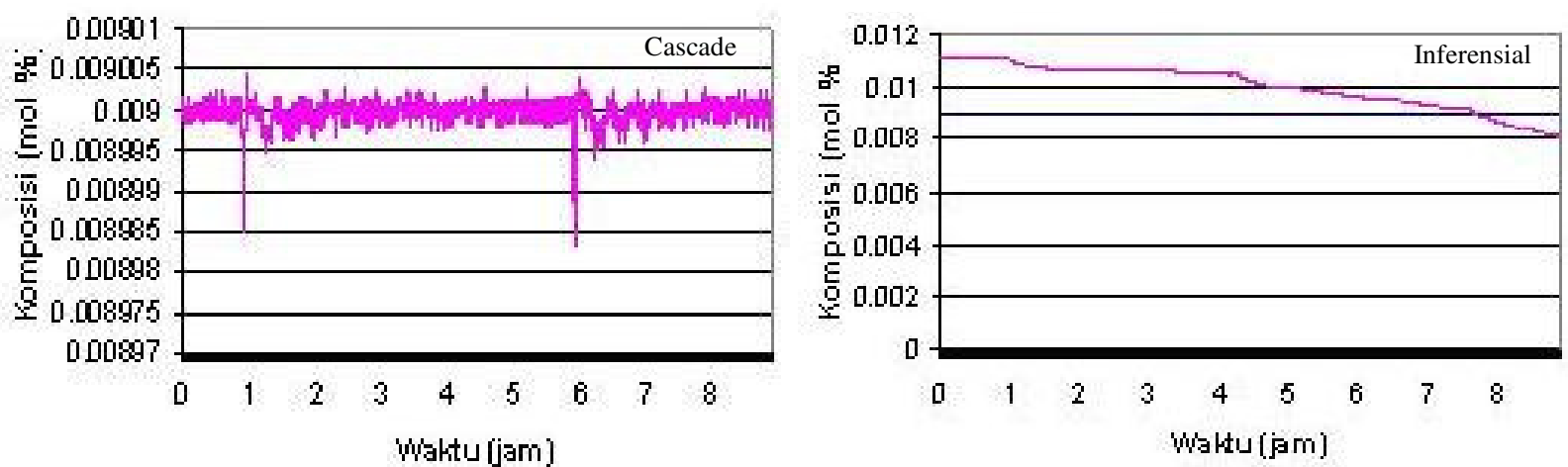

Gambar 10. Xb karena penurunan laju aliran umpan pada kontrol secara cascade dan inferensial 

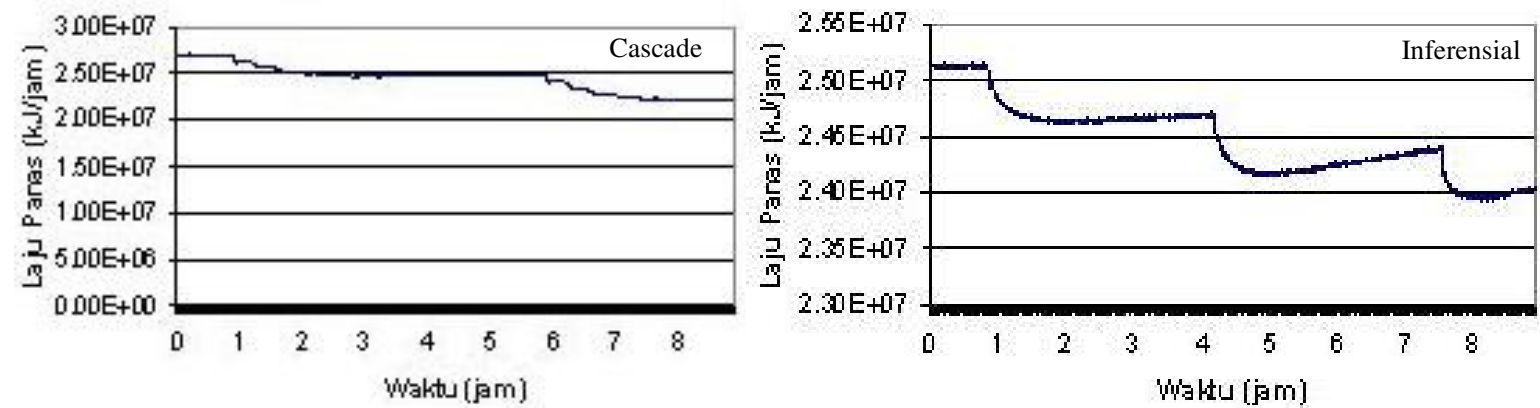

Gambar 11. Qr karena penurunan laju aliran umpan pada kontrol secara cascade dan inferensial

Dilihat dari sisi konsumsi energi kontrol secara cascade lebih banyak pengurangan laju panas reboilernya dibandingkan dengan kontrol secara inferensial. Pada saat terjadi penurunan laju aliran umpan dari $271.27 \mathrm{kmol} / \mathrm{jam}$ hingga $225 \mathrm{kmol} / \mathrm{jam}$, kontrol secara cascade bisa menurunkan laju panas reboiler sebesar $11.16 \%$, yaitu dari $25,100,000 \mathrm{~kJ} / \mathrm{jam}$ turun menjadi 22,300,000 kJ/jam. Bila menggunakan kontrol secara inferensial laju panas reboiler hanya turun sebesar $3.98 \%$ yaitu dari 25,100,000 $\mathrm{kJ} / \mathrm{jam}$ turun menjadi 24,100,000 kJ/jam.

\section{KESIMPULAN}

Dari simulasi diatas dapat ditarik beberapa kesimpulan sebagai berikut :

1. Struktur kontrol secara cascade lebih mampu menjaga kestabilan komposisi produk kolom distilasi aldehid terhadap gangguan berupa penurunan laju aliran umpan.

2. Ketika terjadi gangguan berupa penurunan laju aliran umpan, nilai IAE untuk kontrol secara cascade lebih kecil dari pada kontrol secara inferensial.

3. Penurunan laju panas reboiler ketika terjadi gangguan berupa penurunan laju aliran umpan dari 271.27 $\mathrm{kmol} / \mathrm{jam}$ hingga $225 \mathrm{kmol} / \mathrm{jam}$ adalah $11.16 \%$ untuk kontrol secara cascade dan $3.98 \%$ untuk kontrol secara inferensial.

\section{DAFTAR PUSTAKA}

[1] www.engr.pitt.edu, "Design of a heat-Integrated Distillation Column", 2005.

[2] www.psenterprise.com, "Heat-integrated Distillation Column", 2005.
[3] www.dprin.go.id, "Laporan utama",.2005

[4] Biyanto, TR., Kusmartono, B, Mahfud, AH., "Controllability and Total Annual Cost Analysis of Design and Control Acetone-Ethanol-Butanol Distillation Column with Heat Integration", Journal Academia ISTA Vol.10 No 1, June. 2005

[5] Biyanto, TR., $L V, D V$ and $R R-V$, "Binary Distillation Column Control Performance Evaluation", Industrial Electronic Seminar V 2005, Electronic Engineering Polytechnic Institute of Surabaya - ITS, Surabaya, November $24^{\text {th }} .2005$

[6] Biyanto, TR., "Design of Non Linier Soft sensor for Predict Composition (mole-fraction) distillate and Bottom Product in Single Methanol-water Binary Distillation Column”, International Conference on Instrumentation, Communication and Information Technology (ICICI) 2005 Proc., Universitat Munchen-ITB, Bandung, August 3rd $-5^{\text {th }} .2005$

[7] Luyben, W. L. Bjorn D. Tyreus, Michael L. Luyben, Plant wide Process Control, Mc Graw - Hill, New York. 1998

[8] Zamprogna E., Barolo M. and Seborg D. E., "Neural Network Approach to Composition Estimation in a Middle-Vessel Batch Distillation Column". Proc. DINIP 2000. Workshop on Nonlinear Dynamics and Control in Process Engineering, Rome, June. 2000

[9] Norgaard, M,.Ravn, O., Poulsen, N.K., and Hansen L.K., Neural Network for Modelling and Control of Dynamic Systems, Springer London. 1999

[10] Cybenko G,. "Approximation by Super-position of A Sigmoid Function", Mathematics of Control, Signal, and Systems, Vol. 2(4), 303-314. 1989

[11] Nelles O, Isermann R., "Basis Function Networks for Interpolation of Local Linear Models", Proc.of $35^{\text {th }}$ Conference on Decision and Control, Kobe, Japan, December, 1996 